|| Print ISSN: 2589-7837 || Online ISSN: 2581-3935 || International Journal of Medical Science and Diagnosis Research (IJMSDR)

Available Online at www.ijmsdr.com

NLM (National Library of Medicine ID: 101738824)

\title{
GENE EXPRESSION PATTERN ANALYSIS FOR FORENSIC DIAGNOSIS OF SUDDEN CARDIAC DEATH
}

Saikat Das ${ }^{1}$, Ritwik Ghosh ${ }^{2}$, Dr. Soumeek Chowdhuri ${ }^{3}$

${ }^{1}$ Junior Doctor (MBBS Intern), Calcutta National Medical College, Kolkata

2Junior Doctor (MBBS Intern), Calcutta National Medical College, Kolkata

${ }^{3}$ Tutor, Scottish Awardee (IAFM), Department of Forensic and State Medicine, Calcutta National Medical College, Kolkata

Calcutta National Medical College, Kolkata, India

Conflicts of Interest: Nil

Corresponding author: Saikat Das

DOI: https://doi.org/10.32553/ijmsdr.v4i9.670

\section{Abstract:}

Diagnosis of Sudden cardiac death (SCD) is challenging for forensic experts. In the current scenario, genetic analysis is rapidly gaining interest in forensic science. Previous studies are not only limited to using protein markers. In this regard, analysis of mRNA is also a key feature. Analysing mRNA offers insight into the diseases and mechanisms leading to death. It can also be used for forensic diagnostic purposes. This review article takes the help of this methodology to discuss about those mRNA species that can aid in the process of sudden cardiac death (SCD) diagnosis. These are mRNA encoding Heat Shock Protein (HSP), mRNA encoding Hemoglobin A1/2 \& B, mRNA encoding Pyruvate Dehydrogenase (PDK4), mRNAs encoding Connexin 43 (Cx43) \& Zonula occludens-1 (ZO1), mRNA encoding TNNI3, MYL3, TGFB1, MMP9, VEGFA and mRNA expressing Brain Natriuretic Peptide (BNP).Owing to the difficulty of diagnosing SCD, molecular markers are often developed that can aid in the process. Nowadays, mRNA is showing promising usefulness to supplement the process.

Keywords: Sudden Cardiac Death, forensic, gene expression

\section{Introduction:}

Sudden cardiac death (SCD) is caused by a plethora of varied cardiac diseases. So, it remains a challenge for forensic experts to discover the aetiology and correctly diagnose the cause. The definition of sudden death has been given by WHO as death within 24 hours form the inset of symptoms. The description "sudden" or "unexpected" is not always accurate as unexplained is an equally common reason for medico legal investigation. The clinician is often unable to offer a cause of death though the patient was under medical care and this problem of obscure autopsy is seen. With the emergence of new biochemical techniques, protein markers (1) have been complementarily used with diagnosis of SCD. But the use of histochemical finding can never be avoided. In case of using traditional methods of histochemistry, it has not been possible to diagnose an acute myocardial infarction or ischemia with little time of survival; due to lack of positive pathological findings (2).

However, studies are not only limited to using protein markers. They also involve analysis of gene expression of the individuals. Although RNA is known to be instable; it can be extracted in adequate amount from tissue samples during medico-legal autopsy (3). Unlike RNA with stability ranging from few minutes to days; researchers have confirmed the utility of mRNA, even in samples more than 20 years old (4).

In this article, we have focused on the qualities of mRNA which decide the usefulness of these molecules in diagnosis of SCD during autopsies. We have systematically reviewed different articles for this purpose from databases of PubMed, Google Scholar, etc. Keywords related to the study aim and those included in the search string were: sudden cardiac death, mRNA, forensic diagnosis.

\section{Heat Shock Protein}

Cellular stress response is demonstrated at the time of death and it can induce alterations in mRNA profiles. Heat Shock Proteins (HSP) play vital role in mediating these cell stress responses to extreme conditions of increased temperature, oxidative stress, radiation, exposure to toxic substances and other stimuli (5-7). Demonstrations show that postmortem gene transcripts in brain tissues are relatively more stable compared to others. They remain intact with longer PMI (Postmortem Interval), and are thus suitable for examination of RNA profiles of HSP from cerebral cortex (8-10).

Ischemia (11-13) can cause increase of mRNA levels of HSPA1.They are also reported to be increased in brain after drowning in greater intensity; when compared with other cases of ASP (14). HSPA1 mRNA poses as a potential marker for SCD in acute cases, but have not been expressed significantly (15) during cellular stress (usefulness not concluded).

Attempts were made to analyse HSP mRNA transcripts in postmortem occipital lobes to differentiate causes of death, such as traumatic injury (TI), mechanical asphyxiation (ASP) and sudden cardiac death (SCD) (15). 
HSPA2 mRNA levels were higher in ASP (significant) and SCD subjects (not significant) in comparison to TI. In contrast to this, HSPA7 and A13 mRNA levels were significantly lower in case of both ASP and SCD samples. Interestingly, HSP90AA1 mRNA, which is known as the housekeeping gene, showed significant lower levels in the SCD group than those of ASP. Also, indices for HSPA2:A7/A13 ratios were higher in ASP and SCD subjects in comparison to TI subjects.

It is noteworthy to mention that HSP90AA1 mRNA significantly differentiates between SCD and ASP. Other mRNA profiles although are useful to differentiate ASP \& SCD with TI. They are not able to differentiate between SCD and ASP. This gap is filled by HSP90AA1 mRNA if found appropriate as forensic marker by further studies.

\section{Hemoglobin A1/2 \& B}

High levels of reactive oxygen species (ROS) induce the cellular expression of hemoglobin subunits. The hemoglobin subunits help to protect the cells from oxidative stress (16-18). Since oxidative stress is associated with various modes of heart failure (19-21), prolonged ROS can result in a variety of cardiac dysfunctions leading to cardiac death. These are indicative that mRNA encoding hemoglobin subunits ( $A 1 / 2 \& B$ ) are suitable markers for SCD diagnosis.

Analysis showed that $\mathrm{Hba} 1 / 2$ and $\mathrm{Hbb}$ mRNA from left ventricular free wall tended to be higher in all SCD-related groups (ischemic, non-ischemic \& acute myocardial infraction); than in traumatic death (TD) group by 4 folds (22). In contrast to the findings in myocardial tissues; significant difference in levels of $\mathrm{Hba} 1 / 2$ and $\mathrm{Hbb}$ mRNA from occipital cortexes of brain was not found between SCD and TD cases.

\section{Pyruvate Dehydrogenase (PDK4)}

PDK4, a mitochondrial protein plays a major role in maintaining metabolic flexibility; loss of which leads to onset of cardiovascular complications (23-28). Thus, downregulation of cardiac PKD4 mRNA expression might be related to susceptibility to cardiac dysfunction. Unlike brain samples, analysis of myocardial samples proved that Pkd4 mRNA levels were significantly lower in SCD than TD (22). Also, relative ratio of $\mathrm{Hba} 1 / 2$ or $\mathrm{Hbb}$-to-Pdk4 is seen to be higher in all groups of SCD.

\section{Connexin 43 (Cx43) \& Zonula occludens-1 (ZO1)}

Connexin 43 is a gap junction protein that mediates cell-tocell coupling and is thought to be responsible for propagation of action potential (29). Deterioration in quality of $\mathrm{Cx} 43$, phosphorylation and distribution can cause electrical conductive disorders; ultimately leading to cardiac complications (30).
Zonula occludens-1 (ZO1) is a membrane-associated guanylate kinase that stabilises $\mathrm{Cx} 43$ at gap junction plaque through cytoskeletal anchoring. Disruption of ZO1 leads to alteration in stabilization of the plaque equilibrium (31). Thus, both $\mathrm{CX} 43$ and ZO1 are expected to be indicative of SCD.

Genetic analysis (32) showed that levels of mRNA encoding CX43 and ZO1 were significantly were lower in ventricles in comparison to the atria of heart. Because of the interaction between $\mathrm{Cx} 43$ and ZO1; loss of ZO1 staining in the failing hearts coincide with reduction of $\mathrm{Cx}_{4} 3$ in the individual $(33,34)$, and the genetic analysis also reveals the same.

\section{TNNI3, MYL3, TGFB1, MMP9, VEGFA}

These five proteins (TNNI3, MYL3, TGFB1, MMP9, VEGFA) are related with ischemic myocardial injury and its repair. Cardiac muscle structural protein TNNI3 is quantitively measured clinically for AMI (Acute Myocardial Infraction) diagnosis. MYL3 is also a structural protein in cardiac muscle, level of which changes after ischemic cardiac disease (35-37). TGFFB1, a cytokine protein is strongly activated in infracted myocardium (38-40). MMP9 plays important role in remodelling the vessel matrix after ischemia (41-43). VEGFA is an angiogenic factor that is also activated in ischemic myocardium (44).

Specifically amongst the SCD cases, increased MYL3, VEGFA and MMP9 mRNA values in the anterior wall of the right ventricle were found in genetic analysis (45) when AMI was the cause of death. TNNI3 mRNA expression was found to be unspecific for any particular cause of death. Higher TGFB1 mRNA expression was seen in interventricular septum in $S C D$ cases without AMI, which supports previous studies $(46,47)$; where decreased levels of TGFB1 was found in AMI cases. These indicated that TGFB1 is activated during short survival periods in infracted myocardium (48).

\section{Brain Natriuretic Peptide (BNP)}

BNP and NT-proBNP are considered as reliable biomarkers for diagnosis of cardiac dysfunction. But their usefulness for diagnosis of SCD is arguable (1). The synthesis of BNP is induced by mechanical stress, ischemia and hypoxia; which result in BNP rise in the myocardium (49). In support of this, animal studies (50) demonstrated that BNP mRNA in left ventricle of rats is influenced by Angiotensin II, stimulated by mechanical stress.

In forensic cases such as hemopericardium and pulmonary thromboembolism, mRNA levels in myocardium increased more, in comparison with SCD cases (51). This indicates that BNP mRNA can be used for differential diagnosis. 


\section{Discussion}

In sudden death the immediate cause is almost to be found in the cardiovascular system even though topographically the lesion is not in the heart or great vessels. Ischemic heart disease is the most common cause of death in western countries, but the term has been employed loosely rather inaccurately as it encompasses a number of diseases namely coronary atherosclerosis, hypertensive heart disease, aortic valve disease, anomalies of coronary circulation and other coronary artery disease like polyarteritis (52). All these cases have different pathological manifestations which are indistinguishable from each other when examined by naked eye. This leads to the problem of negative autopsy in such conditions especially as the patient is often health and young. Histopathological and microscopic examination of the cardiac tissue can be of limited use in these conditions. There it is step forward in the diagnosis of such sudden cardiac deaths if a detailed gene expression pattern is known.

Currently, gene expression investigations are gaining interest in forensic medicine. Study of RNA is a key component of such gene expression investigations. However, stability of RNA depends on the type of tissue it originates $(53,54)$. Correlation of RNA degradation with postmortem interval (PMI) is debatable. Best results for postmortem RNA extraction can be obtained from brain, muscle and heart tissue (55). Additionally, other factors such as gender, age at death, temperature, hypoxia and dehydration (56) needs to be discussed specifically for SCD.

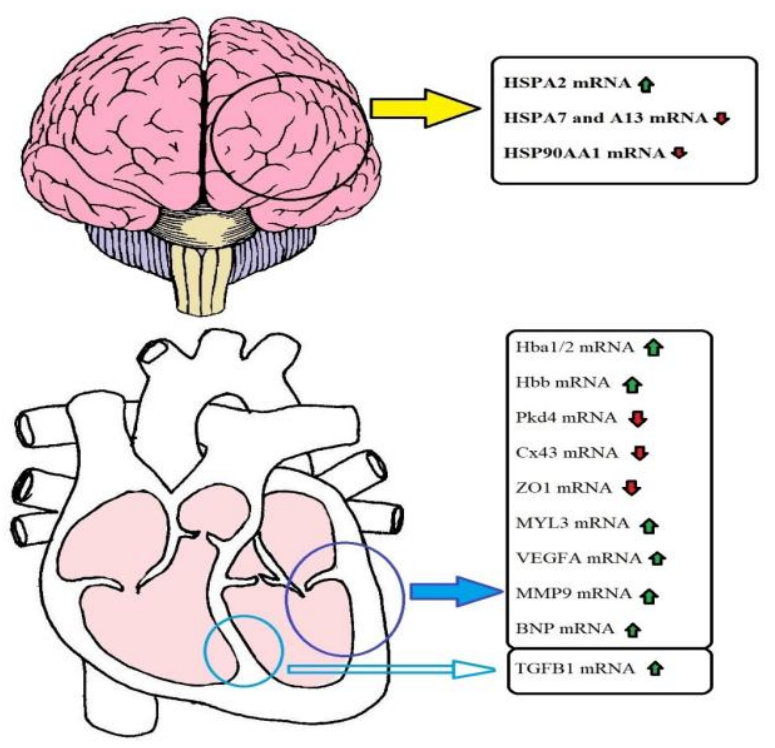

Figure 1: Forensic Diagnosis of SCD: mRNA species extracted from cerebral cortex of brain and ventricular wall \& interventricular septum of heart (up arrow indicates increased level; down arrow indicates decreased level)
The mRNA profiles discussed here (Fig 1) are indicative of $S C D$. Their concentration levels are influenced by the cause of death. Even in cases of SCD due to early infraction, mRNA has shown great potential as biomarker which can be used for forensic diagnostic purposes. Further studies have the scope to explore the quality of SCD diagnosis with increased PMI.

\section{References}

1. Das S, Chowdhuri S, Ghosh R. Biomarkers in Forensic Diagnosis of Sudden Cardiac Death (SCD). Arab Journal of Forensic Sciences \& Forensic Medicine. 2019 May 23; 1(9):1248-1255. (doi: 10.26735/16586794.2019.011)

2. Zhu BL, Ishikawa $T$, Michiue $T$, Li DR, Zhao D, Kamikodai Y, Tsuda K, Okazaki S, Maeda $H$. Postmortem cardiac troponin $\mathrm{T}$ levels in the blood and pericardial fluid. Part 2: analysis for application in the diagnosis of sudden cardiac death with regard to pathology. Legal Medicine. 2006 Mar 1;8(2):94-101.

3. Vennemann $M$, Koppelkamm A. mRNA profiling in forensic genetics I: Possibilities and limitations. Forensic Science International 203 (2010) 71-75

4. Kowalczyk M, Zawadzka E, Szewczuk D, Gryzińska M, Jakubczak A. Molecular markers used in forensic genetics. Medicine, Science and the Law. 2018 Oct;58(4):201-9.

5. Calabrese V, Butterfield DA, Scapagnini G, Stella AG, Maines MD. Redox regulation of heat shock protein expression by signaling involving nitric oxide and carbon monoxide: relevance to brain aging, neurodegenerative disorders, and longevity. Antioxidants \& redox signaling. 2006 Mar 1;8(34):444-77.

6. Romi F, Helgeland G, Gilhus NE. Heat-shock proteins in clinical neurology. European neurology. 2011;66(2):65-9.

7. Stetler RA, Gan Y, Zhang W, Liou AK, Gao Y, Cao G, Chen J. Heat shock proteins: cellular and molecular mechanisms in the central nervous system. Progress in neurobiology. 2010 Oct 1;92(2):184-211.

8. Heinrich M, Lutz-Bonengel S, Matt K, Schmidt U. Realtime PCR detection of five different "endogenous control gene" transcripts in forensic autopsy material. Forensic Science International: Genetics. 2007 Jun 1;1(2):163-9.

9. Leonard S, Logel J, Luthman D, Casanova M, Kirch D, Freedman R. Biological stability of mRNA isolated from human postmortem brain collections. Biological psychiatry. 1993 Mar 15;33(6):456-66.

10. Popova T, Mennerich D, Weith A, Quast K. Effect of RNA quality on transcript intensity levels in microarray analysis of human post-mortem brain tissues. BMC genomics. 2008 Dec 1;9(1):91. 
11. Aoki M, Abe K, Kawagoe JI, Sato S, Nakamura S, Kogure K. Temporal profile of the induction of heat shock protein 70 and heat shock cognate protein 70 mRNAs after transient ischemia in gerbil brain. Brain research. 1993 Jan 22;601(1-2):185-92.

12. Muranyi M, He QP, Fong KS, Li PA. Induction of heat shock proteins by hyperglycemic cerebral ischemia. Molecular brain research. 2005 Sep 13;139(1):80-7.

13. Sharp FR, Kinouchi $H$, Koistinaho J, Chan PH, Sagar SM. HSP70 heat shock gene regulation during ischemia. Stroke. 1993 Dec;24(12 Suppl):I72-5.

14. Gotohda T, Kubo SI, Kitamura O, Tokunaga I, Eguchi A, Orihara Y, Tsuda R, Ikematsu K, Nakasono I. HSP70 and c-Fos expression of brain stem hypoglossal nucleus in drowning. JOURNAL OF MEDICAL INVESTIGATION. 2000 Feb;47(1/2):76-9.

15. Chung $U$, Seo JS, $\operatorname{Kim} Y H$, Son $G H$, Hwang JJ. Quantitative analyses of postmortem heat shock protein mRNA profiles in the occipital lobes of human cerebral cortices: implications in cause of death. Molecules and cells. 2012 Nov 1;34(5):473-80.

16. Arab S, Konstantinov IE, Boscarino C, Cukerman E, Mori A, Li J, Liu PP, Redington AN, Coles JG. Early gene expression profiles during intraoperative myocardial ischemia-reperfusion in cardiac surgery. The Journal of thoracic and cardiovascular surgery. $2007 \mathrm{Jul}$ 1;134(1):74-81.

17. Li X, Wu Z, Wang $Y$, Mei Q, Fu X, Han W. Characterization of adult $\alpha$-and $\beta$-globin elevated by hydrogen peroxide in cervical cancer cells that play a cytoprotective role against oxidative insults. PloS one. 2013;8(1).

18. Liu W, Baker SS, Baker RD, Nowak NJ, Zhu L. Upregulation of hemoglobin expression by oxidative stress in hepatocytes and its implication in nonalcoholic steatohepatitis. PloS one. 2011;6(9).

19. Belch JJ, Bridges AB, Scott N, Chopra M. Oxygen free radicals and congestive heart failure. Heart. 1991 May $1 ; 65(5): 245-8$.

20. Hill MF, Singal PK. Right and left myocardial antioxidant responses during heart failure subsequent to myocardial infarction. Circulation. 1997 Oct 7;96(7):2414-20.

21. Matsushima, S., Kinugawa, S., Ide, T., Matsusaka, H., Inoue, N.,Ohta, Y., Yokota, T., Sunagawa, K., and Tsutsui, H. (2006). Overexpressionof glutathione peroxidase attenuates myocardial remodelling and preserves diastolic function in diabetic heart. Am.J. Physiol. Heart Circ. Physiol. 291, H2237-H2245.

22. Son GH, Park SH, Kim Y, Kim JY, Kim JW, Chung S, Kim $\mathrm{YH}$, Kim H, Hwang JJ, Seo JS. Postmortem mRNA expression patterns in left ventricular myocardial tissues and their implications for forensic diagnosis of sudden cardiac death. Molecules and cells. 2014 Mar 31;37(3):241.

23. Alvarez-Guardia $D$, Palomer $X$, Coll $T$, Davidson $M M$, Chan TO, Feldman AM, Laguna JC, Vázquez-Carrera $M$. The p65 subunit of NF-kB binds to PGC-1 $\alpha$, linking inflammation and metabolic disturbances in cardiac cells. Cardiovascular research. 2010 Aug 1;87(3):44958.

24. Taegtmeyer, H., Razeghi, P., and Young, M.E. (2002). Mitochondrialproteins in hypertrophy and atrophy: a transcript analysis inrat heart. Clin. Exp. Pharmacol. Physiol. 29, 346-350.

25. Zhao, G., Jeoung, N.H., Burgess, S.C., Rosaaen-Stowe, K.A.,Inagaki, T., Latif, S., Shelton, J.M., McAnally, J., Bassel-Duby,R., Harris, R.A., et al. (2008). Overexpression of pyruvate dehydrogenasekinase 4 in heart perturbs metabolism and exacerbatescalcineurin-induced cardiomyopathy. Am. J. Physiol. HeartCirc. Physiol. 294, H936-H943.

26. Meurs, K.M., Lahmers, S., Keene, B.W., White, S.N., Oyama, M.A.,Mauceli, E., and Lindblad-Toh, K. (2012). A splice site mutationin a gene encoding for PDK4, a mitochondrial protein, is associatedwith the development of dilated cardiomyopathy in theDoberman pinscher. Hum. Genet. 131, 1319-1325.

27. Wynn, R.M., Kato, M., Chuang, J.L., Tso, S.C., Li, J., and Chuang,D.T. (2008). Pyruvate dehydrogenase kinase-4 structures reveala metastable open conformation fostering robust core-free basalactivity. J. Biol. Chem. 283, 25305-25315.

28. Sihag, S., Cresci, S., Li, A.Y., Sucharov, C.C., and Lehman, J.J.(2009). PGC-1 $\alpha$ and ERR $\alpha$ target gene downregulation is a signatureof the failing human heart. J. Mol. Cell. Cardiol. 46, 201-212.

29. Kar R, Batra N, Riquelme MA, Jiang JX (2012) Biological role ofconnexin intercellular channels and hemichannels. Arch BiochemBiophys 524(1):2-15

30. Michela P, Velia V, Aldo P, Ada P (2015) Role of connexin 43 incardiovascular diseases. Eur J Pharmacol 768:71-76

31. Gilleron J, Carette D, Fiorini C, Benkdane $M$, Segretain D, PointisG (2009) Connexin 43 gap junction plaque endocytosis impliesmolecular remodelling of ZO-1 and c-Src partners. CommunIntegrBiol 2(2):104-106

32. Xue $Y$, Zhao R, Du SH, Zhao D, Li DR, Xu JT, Xie XL, Wang $Q$. Decreased mRNA levels of cardiac Cx43 and ZO1 in sudden cardiac death related to coronary atherosclerosis: a pilot study. International journal of legal medicine. 2016 Jul 1;130(4):915-22.

33. Hunter AW, Barker RJ, Zhu C, Gourdie RG (2005) Zonulaoccludens-1 alters connexin43 gap junction size and organizationby influencing channel accretion. Mol Biol Cell 16(12):5686-5698 
34. Laing JG, Saffitz JE, Steinberg TH, Yamada KA (2007)Diminished zonula occludens-1 expression in the failing humanheart. Cardiovasc Pathol: Off J Soc Cardiovasc Pathol 16(3):159-164

35. Barton PJ, Buckingham ME. The myosin alkali light chain proteins and their genes. Biochemical Journal. 1985 Oct 15;231(2):249.

36. Barton PJ, Robert B, Fiszman MY, Leader DP, Buckingham ME. The same myosin alkali light chain gene is expressed in adult cardiac atria and in fetal skeletal muscle. Journal of Muscle Research \& Cell Motility. 1985 Aug 1;6(4):461-75.

37. Zhang SZ, Xu Y, Xie HQ, Li XQ, Wei YQ, Yang ZM. The possible role of myosin light chain in myoblast proliferation. Biological research. 2009;42(1):121-32.

38. Dabek J, Kulach A, Wilczok T, Mazurek U, Jakubowski D, Gasior Z. Transcriptional Activity of Genes Encoding Interferon $\gamma$ (IFN $\gamma$ ) and its Receptor Assessed in Peripheral Blood Mononuclear Cells in Patients with Cardiac Syndrome X. Inflammation. 2007 Aug 1;30(34):125-9.

39. Bujak $M$, Frangogiannis NG. The role of TGF- $\beta$ signaling in myocardial infarction and cardiac remodeling. Cardiovascular research. 2007 May 1;74(2):184-95.

40. Frangogiannis NG. Regulation of the inflammatory response in cardiac repair. Circulation research. 2012 Jan 6;110(1):159-73.

41. Lindsey ML. MMP induction and inhibition in myocardial infarction. Heart failure reviews. 2004 Jan 1;9(1):7-19.

42. Peterson JT, Li H, Dillon L, Bryant JW. Evolution of matrix metalloprotease and tissue inhibitor expression during heart failure progression in the infarcted rat. Cardiovascular research. 2000 May 1;46(2):307-15.

43. Vanhoutte $D$, Schellings $M$, Pinto $Y$, Heymans $S$. Relevance of matrix metalloproteinases and their inhibitors after myocardial infarction: a temporal and spatial window. Cardiovascular research. 2006 Feb 15;69(3):604-13.

44. Frangogiannis NG, Smith CW, Entman ML. The inflammatory response in myocardial infarction. Cardiovascular research. 2002 Jan 1;53(1):31-47.

45. González-Herrera $L$, Márquez-Ruiz $A B$, Serrano MJ, Ramos V, Lorente JA, Valenzuela A. mRNA expression patterns in human myocardial tissue, pericardial fluid and blood, and its contribution to the diagnosis of cause of death. Forensic science international. 2019 Sep 1;302:109876.

46. Dabek J, Kulach A, Wilczok T, Mazurek U, Jakubowski D, Gasior Z. Transcriptional Activity of Genes Encoding Interferon $\gamma$ (IFN $\gamma$ ) and its Receptor Assessed in Peripheral Blood Mononuclear Cells in Patients with
Cardiac Syndrome X. Inflammation. 2007 Aug 1;30(34):125-9.

47. Kempf K, Haltern G, Füth R, Herder C, Müller-Scholze $S$, Gülker $H$, Martin S. Increased TNF- $\alpha$ and decreased TGF- $\beta$ expression in peripheral blood leukocytes after acute myocardial infarction. Hormone and metabolic research. 2006 May;38(05):346-51.

48. Nian $M$, Lee $P$, Khaper $N$, Liu P. Inflammatory cytokines and postmyocardial infarction remodeling. Circulation research. 2004 Jun 25;94(12):1543-53.

49. Cao Z, Jia Y, Zhu B. Bnp and nt-probnp as diagnostic biomarkers for cardiac dysfunction in both clinical and forensic medicine. International journal of molecular sciences. 2019 Jan;20(8):1820.

50. Majalahti, T.; Suo-Palosaari, M.; Sarman, B.; Hautala, N.; Pikkarainen, S.; Tokola, H.; Vuolteenaho, O.;Wang, J.; Paradis, P.; Nemer, M.; et al. Cardiac BNP gene activation by angiotensin II in vivo. Mol. CellEndocrinol. 2007, 273, 59-67.

51. Chen, J.H.; Michiue, T.; Ishikawa, T.; Maeda, H. Pathophysiology of sudden cardiac death as demonstratedby molecular pathology of natriuretic peptides in the myocardium. Forensic Sci. Int. 2012, 223, 342-348.

52. Knight B, Saukko P. Knight's Forensic Pathology. Third Edition. London. Arnold; 2004. 492.

53. Heinrich $M$, Matt $K$, Lutz-Bonengel S, Schmidt U. Successful RNA extraction from various human postmortem tissues. International journal of legal medicine. 2007 Mar 1;121(2):136-42.

54. Bahar B, Monahan FJ, Moloney AP, Schmidt O, MacHugh DE, Sweeney T. Long-term stability of RNA in post-mortem bovine skeletal muscle, liver and subcutaneous adipose tissues. BMC molecular biology. 2007 Dec 1;8(1):108.

55. Heinrich $M$, Matt $K$, Lutz-Bonengel $S$, Schmidt $U$. Successful RNA extraction from various human postmortem tissues. International journal of legal medicine. 2007 Mar 1;121(2):136-42.

56. Preece $P$, Cairns NJ. Quantifying $m R N A$ in postmortem human brain: influence of gender, age at death, postmortem interval, brain $\mathrm{pH}$, agonal state and interlobe mRNA variance. Molecular brain research. 2003 Oct 21;118(1-2):60-71. 